\title{
Effects of Abiotic Factors on Phenolic Compounds in the Grape Berry - A Review
}

\author{
E. H. Blancquaert ${ }^{1 *}$, A. Oberholster ${ }^{2}$, J. M. Ricardo-da-Silva ${ }^{3}$, A.J. Deloire ${ }^{4}$
}

(1) Department of Viticulture and Oenology, Stellenbosch University, Private Bag X1, Matieland, 7602, South Africa

(2) Department of Viticulture and Enology, University of California, Davis, CA 95616, USA

(3) LEAF - Linking Landscape, Environment, Agriculture and Food, Laboratório Ferreira Lapa (Sector de Enologia), Instituto Superior de Agronomia, Universidade de Lisboa, 1349-017 Lisboa, Portugal

(4) SupAgro, Department of Biology and Ecology, Montpellier University, 34060 Montpellier, France

Submitted for publication: May 2018

Accepted for publication: September 2018

Key words: Flavan-3-ols, anthocyanins, flavonols, ripening, light, temperature, UV-radiation

Grape berry phenolic compounds are widely described in literature. Phenolics can be divided into two main groups: flavonoids and non-flavonoids, of which the flavonoids are the most important. The two bestknown groups of flavonoids are the anthocyanins and condensed tannins (also called proanthocyanidins). Anthocyanins are responsible for the red colour in grapes. The condensed tannins (proanthocyanidins) are responsible for some major wine sensorial properties (astringency, browning, and turbidity) and are involved in the wine ageing processes. This review summarises flavonoid synthesis in the grape berry and the impact of environmental factors on the accumulation rate during ripening of each of the flavonoids. The impact of the accumulated flavonoids in grapes and the resulting impact on the sensorial aspects of the wine are also discussed.

\section{INTRODUCTION}

Globally, grapes are one of the most widely cultivated crops. In 2012, grapes covered 7.5 million hectares of arable land (OIV, 2013). Most of the grapes are fermented into wine, or used for table grapes and raisin production. Many researchers have shown that the growing site (climate and soil) and viticultural practices have a direct impact on grape maturity and the phenolic composition of the berry. Flavonoids play an important role in grape and wine quality. Therefore, an in-depth understanding of flavonoid development and composition during berry development under South African climatic conditions is needed.

Grape berry development involves a complex series of physical and biochemical changes. These can be divided into three major phases: green growth (Stage I), the lag phase (Stage II), and the ripening phase (Stage III). During these three phases, primary and secondary metabolites are synthesised under complex gene and enzymatic control. Primary metabolites such as sugars, amino acids and organic acids are involved in normal growth, development, and reproduction of plant species. Secondary metabolites such as phenolics and stilbenoids have ecological functions. These ecological functions include defence against predators, parasites and diseases (Conde et al., 2007; Ali et al., 2010). Phenolic compounds have a diversity of structures and can be divided into two main groups, namely flavonoids and non- flavonoids (Cheynier et al., 2006). The phenolic compounds of interest in this study are the flavonoids, and they will be discussed in depth in the following paragraphs.

\section{Flavonoid biosynthesis}

Flavonoid biosynthesis is the result of the shikimate and phenylpropanoid pathways (Dewick \& Haslam, 1969; Heller \& Forkmann, 1988). Flavonoids are characterised by two benzene rings (rings A and B) bonded by an oxygenated heterocyclic pyran ring (ring $\mathrm{C}$ ). They therefore possess a $\mathrm{C}_{6}-\mathrm{C}_{3}-\mathrm{C}_{6}$ skeleton (Fig. 1) (Somers \& Vérette 1988; Ribérau-Gayon, 2000). The heterocyclic ring is closed in most flavonoids, but remains open in chalcones and dihydrochalcones (Stafford, 1990). Variation in the oxidation state and substitution on ring $\mathrm{C}$ define the different classes of flavonoids (Fig. 1).

\section{Flavan-3-ols}

Flavan-3-ols are the most abundant class of flavonoid compounds in grape berries (Adams, 2006; Terrier et al., 2009). Flavan-3-ols comprise monomers (catechins), oligomers, and polymers. They are also referred to as proanthocyanidins or condensed tannins (Cheynier \& Rigaud, 1986; Ricardo-da-Silva et al., $1991 \mathrm{a}, \mathrm{b}$ ). The major flavan-3-ol monomers in grape seeds are $(+)$-catechin, 
(O)

C ring substitution<smiles>CC1=C(C)OC(C)C(O)C1</smiles><smiles>Cc1c(O)c(C)c2c(c1O)C(C)C(O)C(C)O2</smiles>

\section{Class}

Flavan-3-ol

\section{Basic structure}<smiles>Oc1cc(O)c2c(c1)Oc1c(O)cc(O)cc1O[C@H](c1ccc(O)c(O)c1)[C@H](O)C2</smiles>

Proanthocyanidin<smiles>COCCO</smiles>
$\mathrm{n}=1,2,3$

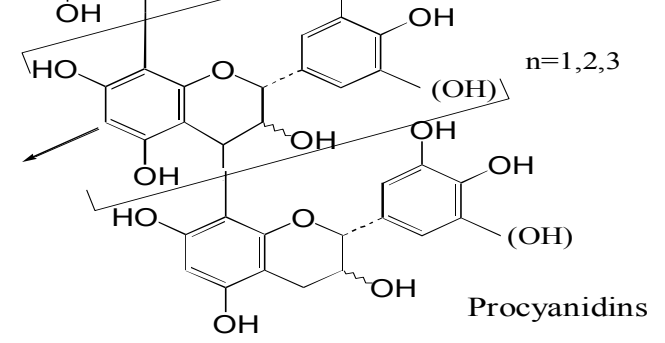

Anthocyanin<smiles></smiles>

Malvidin-3-glucoside

FIGURE 1

Flavonoid nomenclature (Somers \& Vérette, 1988).

(-)-epicatechin and a galloylated form of (-)-epicatechin-3$O$-gallate (Fig. 2). (-)-Epigallocatechin and trace amounts of $(+)$-gallocatechin are also found in grapes. Flavan-3-ols in grape skins are represented by $(+)$-catechin, (-)-epicatechin, (-)-epicatechin-3-O-gallate and (-)-epigallocatechin. The presence of $(+)$-gallocatechin in Vitis vinifera has been reported while $(+)$-catechin-2-gallate and $(+)$-gallocatechin3 -gallate have been detected in some non-Vinifera varieties (Piretti et al., 1976; Czochanska et al., 1979; Lee \& Jaworski, 1987). Condensed tannins are formed during the polymerisation process and comprise flavan-3-ol subunits connected by interflavan linkages $\left(\mathrm{C}_{4}-\mathrm{C}_{8}\right.$ or $\left.\mathrm{C}_{4}-\mathrm{C}_{6}\right)$ (Fig. 3) (Haslam, 1998).

Proanthocyanidins, or condensed tannins, are mostly situated in the solid parts of the cluster (skins, seeds and stems) and, to a lesser degree, in the pulp (Sun et al., 1999; Jordão et al., 2001; Ó-Marques et al., 2005). Seeds have the highest concentration of procyanidins (Ricardo-da-Silva et al., 1992a). Within the grape berry, proanthocyanidins or condensed tannins are situated in the hypodermal layers of the skin and the soft parenchyma of the seed between the cuticle and the hard seed coat (Adams, 2006).

Skintannins exhibitahigher degree of polymerisation than seed tannins, expressed as the mean degree of polymerisation (mDP) (Adams, 2006). Kennedy et al. (2000a) and Downey et al. (2003a) found proanthocyanidin polymers with $25-40$ subunits comprising equal proportions (-)-epicatechin and (-)-epicatechin-3-O-gallate with $(+)$-catechin as terminal subunits. The polymer length remained constant until veraison. Polymer length decreased to about 30 subunits four weeks after veraison and to approximately 20 subunits at harvest (Kennedy et al., 2000a; Downey, et al., 2003a). The mDP in seeds varies between three to sixteen subunits comprising (+)-catechin, (-)-epicatechin and (-)epicatechin3-O-gallate (Cheynier et al., 1998; Downey et al., 2003a; Bogs et al., 2005; Mané et al., 2007). From fruit-set to one 


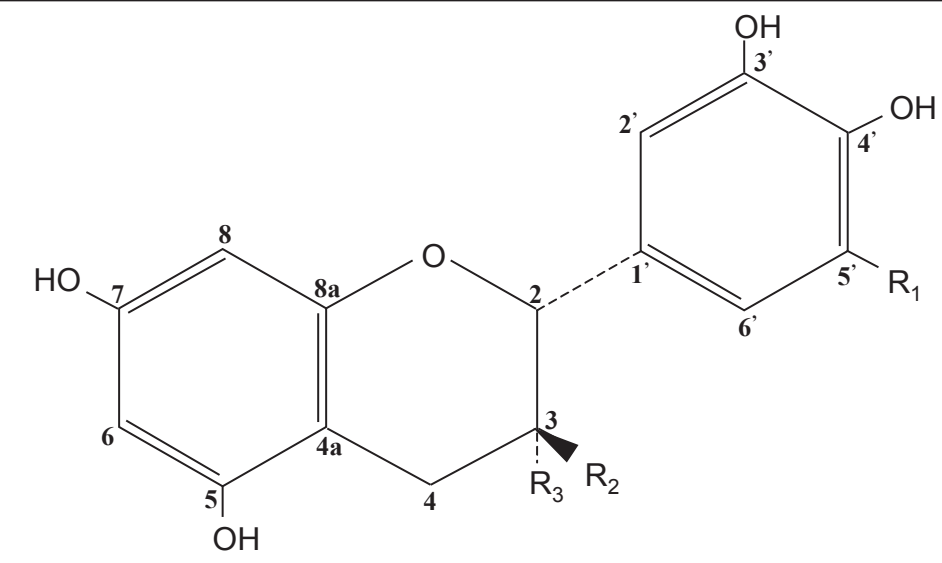

\begin{tabular}{|l|c|c|c|}
\hline & $\mathrm{R}_{1}$ & $\mathrm{R}_{2}$ & $\mathrm{R}_{3}$ \\
\hline (+)-catechin & $\mathrm{H}$ & $\mathrm{OH}$ & $\mathrm{H}$ \\
(+)-gallocatechin & $\mathrm{OH}$ & $\mathrm{OH}$ & $\mathrm{H}$ \\
(-)-epicatechin & $\mathrm{H}$ & $\mathrm{H}$ & $\mathrm{OH}$ \\
(-)-epigallocatechin & $\mathrm{OH}$ & $\mathrm{H}$ & $\mathrm{OH}$ \\
\hline
\end{tabular}

FIGURE 2

Chemical structures of flavanols (Moutounet et al., 1996).

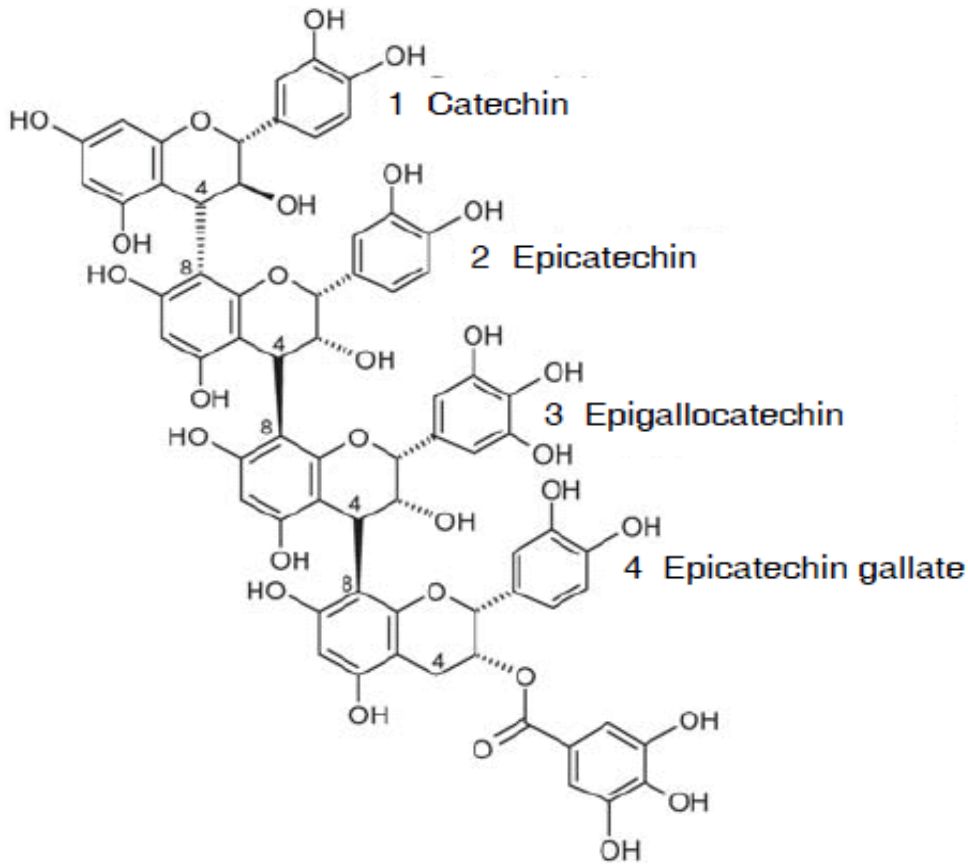

FIGURE 3

Condensed tannin and the four subunits: (+)-catechin, (-)-epicatechin, (-)-epigallocatechin and (-)-epicatechin gallate (Adams, 2006).

week pre-veraison, polymer length remained between five and six subunits. An increase in the terminal subunits one week pre-veraison exceeded the accumulation of extension subunits, resulting in a decrease in polymer length to four subunits (Downey et al., 2003a). Various average ranges of $\mathrm{mDPs}$ are reported for proanthocyanidins in grape berries. Prieur et al. (1994), Moutounet et al. (1996) and Labarbe et al. (1999) reported seed mDP ranging between 8 and 16 units for grape seeds, whilst Mané et al. (2007) reported values between 3 and 4 units. Skin mDP ranges between 27 and 45 units on average (Moutounet et al., 1996; Souquet et al., 1996; Mané et al., 2007).

The flavan-3-ols are synthesised as part of the phenylpropanoid pathway (Fig. 4). Other secondary 


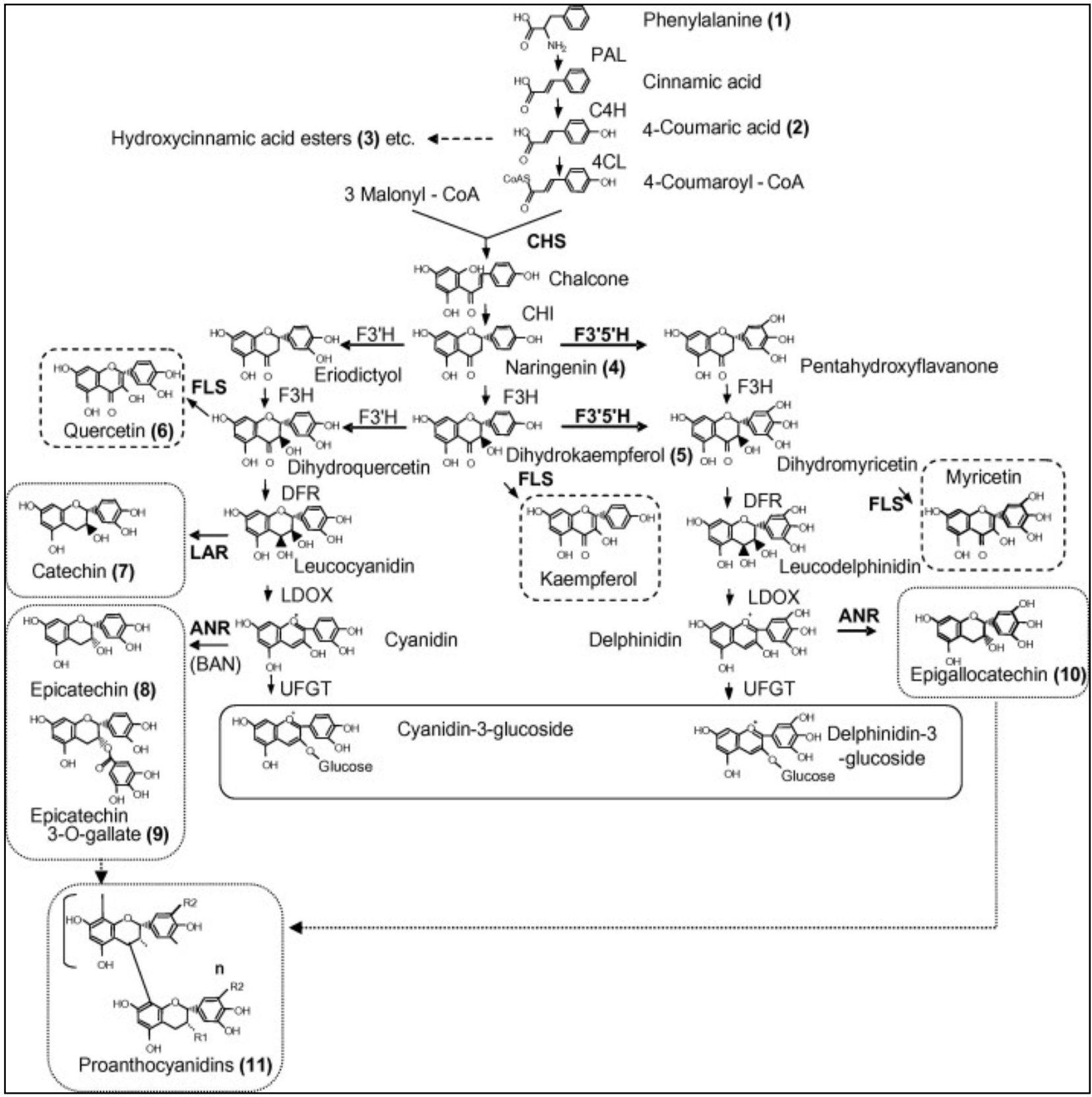

FIGURE 4

Phenylpropanoid pathway in the grape berry (Koyama et al., 2012).

metabolites such as lignins, lignans, stilbenes and hydroxycinnamic acids are also produced in this pathway (Schwinn \& Davies, 2004). Phenylalanine (obtained via the shikimate pathway) and malonyl-CoA (derived from citrate produced by the tricarboxylic acid cycle) (Davies \& Schwinn, 2006) are the main flavonoid precursors. Phenylalanine is converted into the activated hydroxycinnamic acid p-coumaroyl-CoA by three enzymatic conversions and catalysed by phenylalanine ammonia-lyase (PAL), cinnamate 4-hydroxylase and 4-coumarate-CoA ligase. Malonyl$\mathrm{CoA}$ is required for flavonoid biosynthesis and acts as an "extender" molecule and acid moiety donor for acylation of flavonoid glycosides that form the first flavonoid. The point of entry into the flavonoid pathway is the formation of a chalcone (mostly naringenin). The chalcone is formed from
p-Coumaroyl-CoA and three acetate units from malonylCoA through the action of chalcone synthase (CHS). The chalcone then gives rise to a flavonoid with a $\mathrm{C} 15$ backbone, which is directly or indirectly converted to a range of other flavonoids in a pathway of intersecting branches with intermediate compounds (Schwinn \& Davies, 2004). A flavonoid with a heterocyclic C-ring is isomerised to a flavanone through the activity of chalcone isomerase (CHI) (Schwinn \& Davies, 2004). Hydroxylation of flavanones is catalysed by flavanone $3 \beta$-hydroxylase $(\mathrm{F} 3 \mathrm{H})$, which results in dihydroflavonols. The latter is then subjected to catalysis by dihydroflavonol 4-reductase (DFR) resulting in leucocyanidins that are colourless and unstable compounds. Proanthocyanidins are formed through interflavan linkages between the flavan-3-ol building blocks. Flavan-3-ols are 
formed via two biosynthetic routes: (i) 2,3-trans-flavan-3ols are produced from leucocyanidins by leucoanthocyanidin reductase (LAR); and (ii) 2,3-cis-flavan-3-ols from cyanidin by anthocyanidin reductase (ANR). LAR removes the 4-hydroxyl from leucocyanidins to produce 2,3-trans-flavan3-ols while the ANR converts cyanidin to the corresponding 2,3-cis-flavan-3-ols (Tanner et al., 2003; Xie et al., 2003) (Fig. 5). Flavan-3-ols are synthesised in the cytoplasm and transported to the vacuoles where polymerisation occurs and proanthocyanidins accumulate.

\section{Anthocyanins}

In the final step of anthocyanidin-3-O-glycoside biosynthesis, pigments are formed through the activity of anthocyanidin synthase, also referred to as leucoanthocyanidin dioxygenase (LDOX), which is also an anthocyanidin-3-glycosyltranferase to the corresponding anthocyanin (Fig. 5) (Davies \& Schwinn, 2006). Schwinn \& Davies (2004) suggested that hydroxylation has a key impact on anthocyanin colour. An increase in hydroxylation of the B-ring results in the shift in colour from red to blue, determining the type of anthocyanin produced.

\section{Flavonols}

Flavonols are flavonoids found in higher plants in glycosidic forms developed during the flavonoid biosynthetic pathway (Mattivi et al., 2006). Synthesis of flavonols predominately occurs in the grape skin (Price et al., 1995). Quercetin-3$O$-glucoside and quercetin-3-O-glucuronide have been identified as the main flavonols within the grape berries (Cheynier et al., 1986; Price et al., 1995; Downey et al., 2003b). Various researchers have investigated the molecular structure and the expression of the main enzymes, and a general pathway for flavonol biosynthesis has been established (Downey et al., 2003b; Bogs et al., 2006; Castellarin et al., 2006; Mattivi et al., 2006) (Fig. 6).

\section{Changes in flavonoid content with ripening}

It is clear that flavonoid biosynthesis is influenced by berry maturation. The grape seed tannin biosynthesis studied in grape cultivars such as Cabernet Sauvignon, Shiraz, and Pinot noir indicated an overall tendency for the maximum concentration to be reached at veraison, decreased thereafter, and to remain constant during maturation (Kennedy et al., 2000a; Kennedy et al., 2000b; Jordão et al., 2001; Downey et al., 2003b; Downey et al., 2006). Other studies reported that the concentration and composition were influenced by grape variety and the vintage (Ricardo-da-Silva et al., 1991c \& 1992b; Jordão et al., 2001). Ribereau-Gayon et al. (2000) suggested that grape cultivars such as Cabernet franc, Pinot noir, Grenache, and Tempranillo generally have higher levels of seed tannin compared to Cabernet Sauvignon and Merlot noir. As for grape skin tannin, investigators found a higher concentration at fruit set and noted a decrease and then an increase around veraison, followed by another decrease (Kennedy et al., 2001; Kennedy et al., 2002a; Downey et al., 2003a).

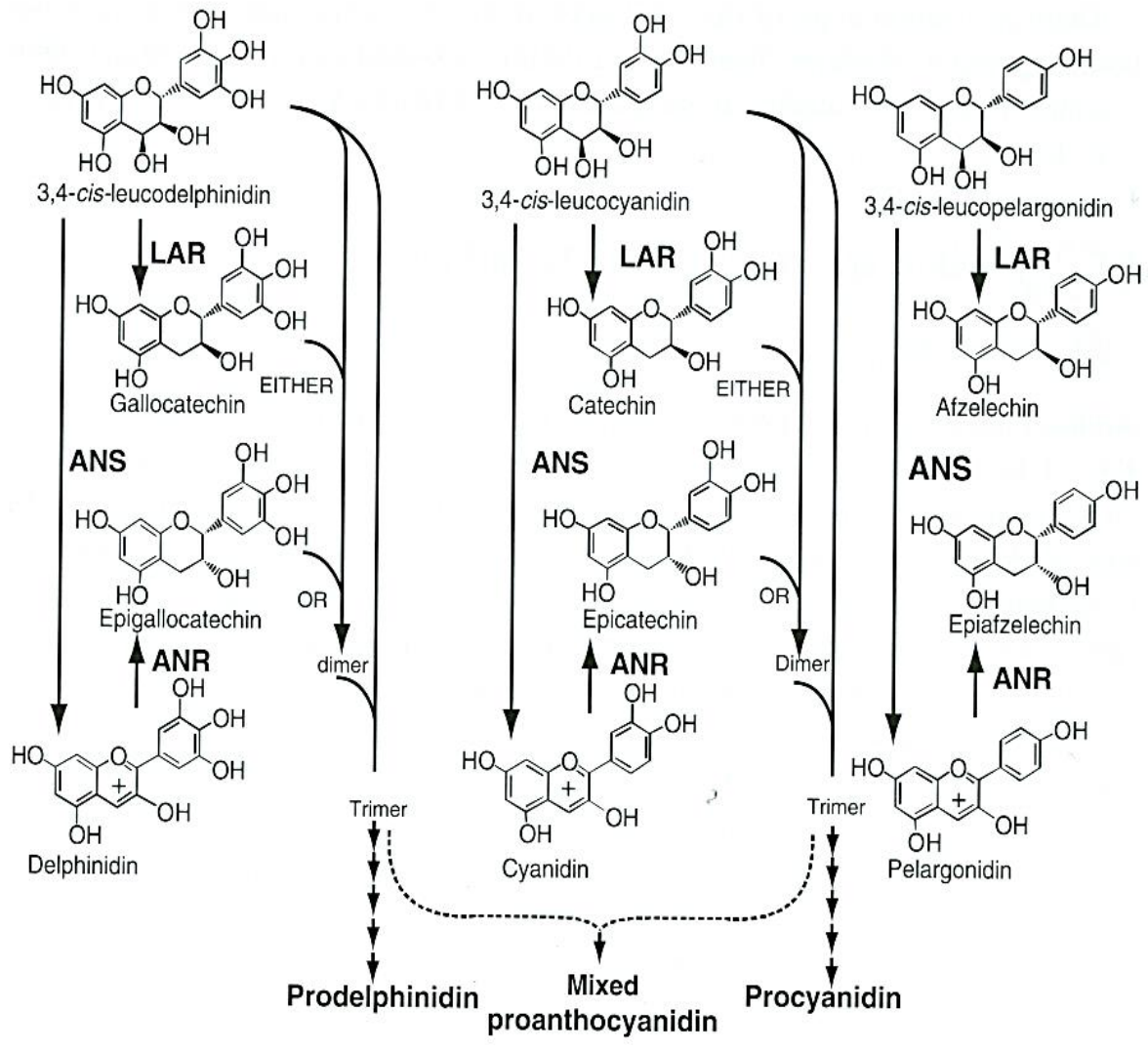

FIGURE 5

Biosynthesis of flavan-3-ols and proanthocyanidins (Tanner, 2006). 


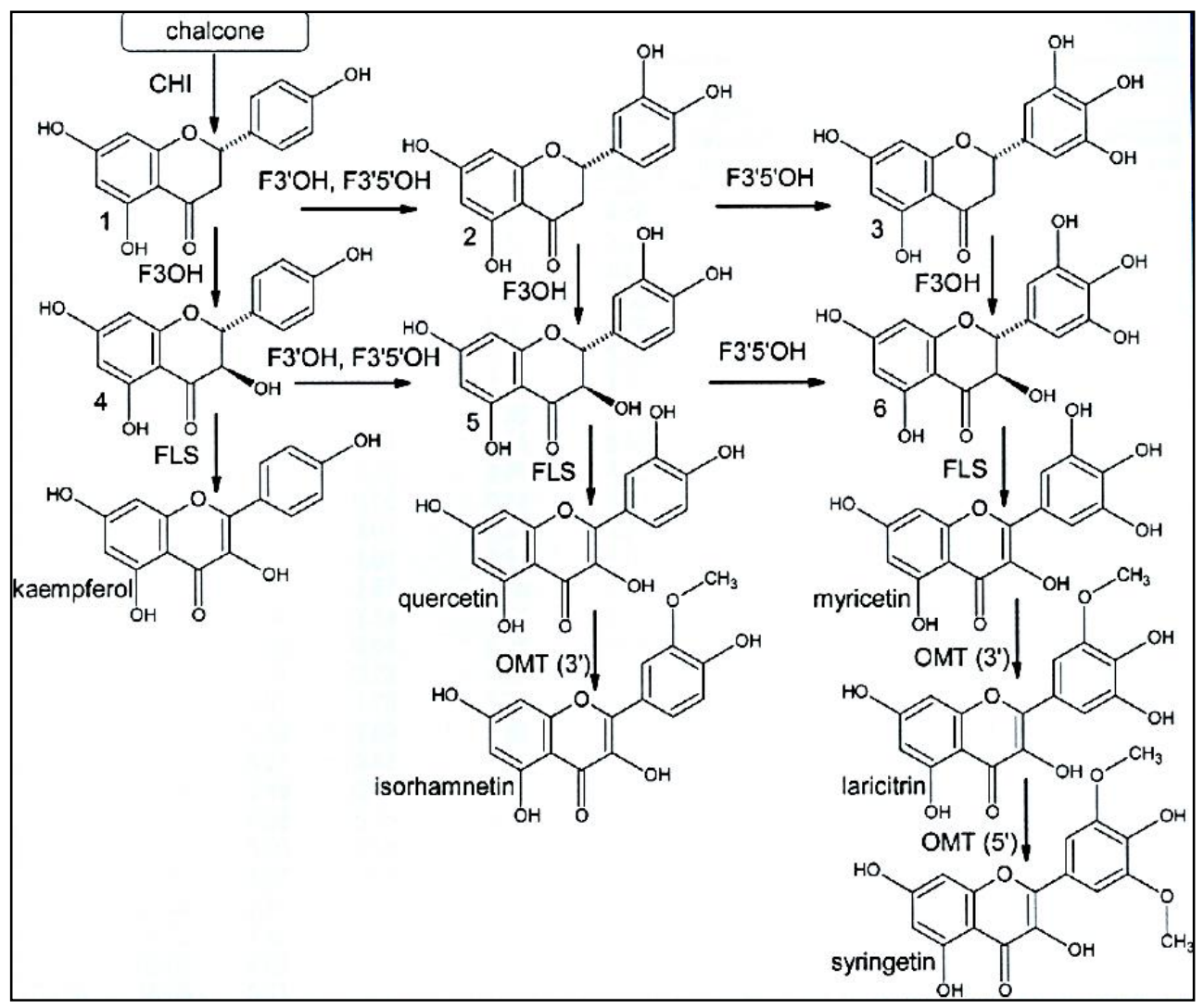

FIGURE 6

General pathway for flavonol biosynthesis (Mattivi et al., 2006).

Various researchers suggested that anthocyanin development and composition are influenced by cultivar, climatic conditions (abiotic factors such as light, temperature, and water), and viticultural practices (Kliewer \& Torres, 1972; Jackson \& Lombard, 1993; Dokoozlian \& Kliewer, 1996; Bergqvist et al., 2001; Spayd et al., 2002; Downey et al., 2004). Downey et al. (2003b) reported that the total concentration of flavonols in berries was low pre-veraison, and then increased post-veraison. Flavonoid composition clearly changes with ripening and research indicates potential influences of environmental parameters such as temperature and light.

\section{Environmental factors affecting development of phenolic compounds in grape berries}

\section{Cultivar and seasonal variability affecting flavonoid development}

In light of global climate change, numerous authors proposed climatic models to forecast the impact on grape and wine quality as well as production (Jones et al., 2000; Jones et al., 2005; Orduña, 2010). These climatic models encompass air temperature as well as relative humidity, precipitation and viticultural records (Stock et al., 2004; Jones et al., 2005). Temperature increases between 2002 and 2049 of $0.42^{\circ} \mathrm{C}$ per decade and $2.04^{\circ} \mathrm{C}$ overall is predicted. In both the Northern and Southern hemisphere, authors found that an increase in seasonal temperatures, solar radiation and rainfall had an impact on the length of the season, sugar concentration and the potential alcohol level of the fermented wines (Laget et al., 2008; Jones et al. 2000; Petrie et al., 2008).

Phenolic development is impacted by the abovementioned environmental parameters as well as the genetic factors (Cohen \& Kennedy, 2010; Orduña, 2010; Castellarin et al., 2012). Furthermore, the cultivation practices and resulting microclimate around the developing fruit affect the fruit composition, for example total soluble solids, flavan-3ol monomers, proanthocyanidins, and pigmented polymers (Cortell et al., 2005). Environmental factors such as sunlight, temperature, ultra-violet (UV) radiation, and plant water status play a role in the accumulation of proanthocyanidins, flavonols, and anthocyanins (Table 1) (Crippen \& Morrison, 1986; Kennedy et al., 2002b; Ojeda et al., 2002; Downey et al., 2004; Mori et al., 2005 \& 2007; Buchetti et al., 2011; Gregan et al., 2012; Koyoma et al., 2012; Reshef et al., 2018).

\section{Light}

Plant metabolism is greatly dependent on solar effects (Cohen $\&$ Kennedy, 2010). Zucker (1965) found that the functioning of PAL is affected by white light (visible light spectrum). Dokoozlian and Kliewer (1996) found that exposure of berries during growth stages I (green growth stage), and II (lag phase) resulted in an increased PAL, which resulted in a higher anthocyanin concentration. Investigations into the effect of light on grape composition resulted in varying outcomes, as described below.

Haselgrove et al. (2000) and Spayd et al. (2002) studied the impact of light on Shiraz and Cabernet Sauvignon 
TABLE 1

Grapevine fruit responses to environmental factors (adapted from Cohen \& Kennedy, 2010).

\begin{tabular}{|c|c|c|}
\hline Phenolic compounds & $\begin{array}{l}\text { Environmental } \\
\text { factors }\end{array}$ & Responses \\
\hline \multirow[t]{4}{*}{ Anthocyanin } & Light intensity & $\begin{array}{l}\text { Increase per berry content in sun exposed versus canopy shaded fruit } \\
\text { (Crippen \& Morrison, 1986). } \\
\text { Exposed berries (increase in per berry content) (Downey et al., 2004). }\end{array}$ \\
\hline & UV exposure & $\begin{array}{l}\text { Total monomeric skin anthocyanin (TMSA) concentrations were not } \\
\text { influenced by UV radiation, but rather by the visible spectrum of light and } \\
\text { temperature, which played a crucial role (Spayd et al., 2002). }\end{array}$ \\
\hline & Temperature & $\begin{array}{l}\left.\text { Decrease at high temperatures }\left(30^{\circ} \mathrm{C}-35^{\circ} \mathrm{C}\right) \text { (Mori et al., } 2005 \& 2007\right) \text {. } \\
\text { Cooler temperatures increased TMSA (Spayd et al., 2002) } \\
\text { More anthocyanins at } 20^{\circ} \mathrm{C} \text { than at } 30^{\circ} \mathrm{C} \text { (Yamane } \text { et al., 2006). }\end{array}$ \\
\hline & Irrigation & $\begin{array}{l}\text { Water deficit increased concentration (Koundouras et al., 2005). } \\
\text { Early irrigation/severe deficit: lower concentration and amount per berry } \\
\text { (Ojeda } \text { et al., 2002). }\end{array}$ \\
\hline \multirow[t]{4}{*}{ Flavonols } & Light intensity & $\begin{array}{l}\text { Increased concentration with exposure (Price et al., 1995; Spayd et al., } \\
\text { 2002; Koyama et al., 2012; Gregan et al., 2012). }\end{array}$ \\
\hline & UV exposure & $\begin{array}{l}\text { Exclusion of solar UV radiation remarkably decreased concentration } \\
\text { (Koyama et al., 2012). } \\
\text { Increase when UV transmitting barriers were used (Spayd et al., 2002). } \\
\text { Increase in flavonol concentration under high UV light exposure (Reshef } \\
\text { et al., 2018). }\end{array}$ \\
\hline & Temperature & No effect (Mori et al., 2005). \\
\hline & Irrigation & $\begin{array}{l}\text { Deficit increased concentration (between anthesis and veraison, and veraison } \\
\text { and harvest) (Ojeda et al., 2002). }\end{array}$ \\
\hline \multirow[t]{4}{*}{ Proanthocyanidins (PAs) } & Light intensity & $\begin{array}{l}\text { Exposure lead to an increase per berry, whilst shade resulted in an increase } \\
\text { in substitution positions within the molecule (Downey et al., 2004). } \\
\text { Exposure resulted in an increase in seeds and skins mDP (Downey et al., } \\
\text { 2004). }\end{array}$ \\
\hline & UV exposure & $\begin{array}{l}\text { UV exclusion did not affect the concentration and composition of PAs } \\
\text { (Koyama et al., 2012). }\end{array}$ \\
\hline & Irrigation & $\begin{array}{l}\text { Post-veraison affected total flavan-3-ol monomers in } \\
\text { seed tissue, mainly as a result of variations in the catechin amount } \\
\text { (Koundouras et al., 2009). } \\
\text { Water deficits over four seasons increased tannin concentration less and only } \\
\text { by reducing fruit growth, except in one year where the tannin content was } \\
\text { increased (Bucchetti et al., 2011). }\end{array}$ \\
\hline & Temperature & $\begin{array}{l}\text { Heating and cooling berries altered the initial accumulation rate (via } \\
\text { biosynthesis) pre-veraison (Cohen et al., 2012). }\end{array}$ \\
\hline
\end{tabular}

berries, respectively. According to Haselgrove et al. (2000), berries that received high levels of sunlight had high levels of quercetin-3-glucoside and low levels of malvidin-3glucoside. The total anthocyanin levels varied between treatments and depended on the degree of bunch exposure. Spayd et al. (2002) found that berries that were exposed to sunlight had increased total skin monomeric anthocyanins regardless of the ambient temperature. Subsequent investigations showed that low light also reduced colour in Emperor table grapes and in Pinot Noir (Kliewer 1970, 1977). Similar results were later reported in Shiraz (Smart et al., 1985) and Cabernet Sauvignon grapes (Morrison \& Noble, 1990; Hunter et al., 1991; Dokoozlian \& Kliewer, 1996). Together these results created a strong impression that light was necessary for colour formation in grapes, an impression reinforced by observations from other plant species, such as apple, where light is an absolute requirement for anthocyanin biosynthesis (Siegelman \& Hendricks, 1958; Chalmers \& Faragher, 1977; Lancaster, 1992; Dong et al., 1998). Wicks and Kliewer (1983) and Dokoozlian and Kliewer (1996) suggested that low light intensity reduced anthocyanins and some other flavonoids, while enhanced light intensity increased the flavonoid content of grapes. Results of these studies indicate that light is important in the colour formation in grapes. This theory is also supported for anthocyanin biosynthesis in other plant species such as apples (Siegelman \& Hendricks, 1958; Lancaster, 1992; Dong et al., 1998). 
However, some investigations found contradictory results. Crippen \& Morrison (1986) found that there were no significant differences in the anthocyanin concentration and content at harvest between sun-exposed and shaded grapes, although there were differences during berry development. Others reported that high light intensities $\left(>100 \mu \mathrm{mol} \mathrm{m}{ }^{-2} \cdot \mathrm{s}^{-1}\right)$ resulted in decreased anthocyanin levels (Bergqvist et al., 2001; Spayd et al., 2002). Ristic et al. (2007) found that the anthocyanin content of grapes in a shade box treatment versus the non-shaded treatment did not differ significantly. Only a change in the deoxygenated anthocyanins was observed, as well as an increase in seed tannin and decrease in skin tannin between the shaded and non-shaded treatments, respectively. In a study on vine vigour, Cortell et al. (2005) found that seed proanthocyanidin composition in grapes was slightly different between vigour zones identified as high, medium and low, but the total amount was not affected. The total amount of epigallocatechin and $\mathrm{mDP}$ values of the skin proanthocyanidins was increased in the low vigour vines (vigour index of 0.09 and 0.44 , respectively).

Many explanations have been suggested for the abovementioned differences in results ranging from differences in cultivar sites, vine vigour, vintage effects, sampling method, and the analytical technique used (Cortell et al., 2005; Downey et al., 2006; Bucchetti et al., 2011). Therefore, it can be deduced that:

a) controlled conditions (e.g. greenhouse or growth chamber) are desirable to study the effect of abiotic factors (light intensity and quality, temperature and water) on berry phenolic composition; and

b) data should be presented on a per berry basis and in concentration to understand the dynamic of berry phenolic biosynthesis from berry set to maturation as well as the impact on overall concentration.

\section{Temperature}

An increase in plant temperature, either through direct heating by incident radiation or increased air temperatures, will increase the rate of metabolic processes in the plant, with an associated increase in development and metabolite accumulation (Hawker, 1982; Ebadi et al., 1995; Dokoozlian \& Kliewer, 1996; Downey et al., 2006). The accumulation/ biosynthesis of total soluble solids and organic acids, the biosynthesis of aromatic precursors and colour components, and the process of photosynthesis are all enzyme-driven and therefore regulated by temperature, light, and plant water status (Jackson \& Lombard, 1993).

Gladstones (1992) suggests that pigment formation and the optimal physiological ripening of grapes for the synthesis of colour and aroma compounds take place between $20^{\circ} \mathrm{C}$ and $22^{\circ} \mathrm{C}$. When the day temperature is high, low night temperatures are necessary to ensure a low $\mathrm{pH}$ and high natural acidity (Jackson \& Lombard, 1993). Mori et al. (2005) found that metabolic pathways are altered when the ambient temperature reaches $30^{\circ} \mathrm{C}$. Martínez-Lüscher et al. (2017) found that the use of colour shade nets efficiently palliate temperature a few weeks prior to harvest whilst transmitting enough radiation into the bunch zone.

Chorti et al. (2010) and Mori et al. (2005) found that high night temperatures resulted in a decrease in the anthocyanin accumulation within the berry, but there was no change in the flavonol concentration. However, high temperatures inhibited the gene expression of $\mathrm{CHS}, \mathrm{F} 3 \mathrm{H}$, dihydroflavonol 4-reduxtase (DFR), leucoanthocyanidin dioxygenase (LDOX), and UDP-glucose. Flavonoid 3-Oglucosyltransferase (UFGT) activity decreased at veraison and was followed by an increase after veraison (Mori et al., 2005). Buttrose et al. (1971) found that if the day temperatures were constant at $20^{\circ} \mathrm{C}$ for Cabernet Sauvignon, it was favourable for colour formation, but day temperatures $>30^{\circ} \mathrm{C}$ resulted in less colour. Recently, Tarara et al. (2008) found that low light and high berry temperatures decreased the total skin anthocyanin (TSA). These findings are supported by the findings of Coombe (1987), which suggested that the primary metabolism of the berry is optimal at approximately $30^{\circ} \mathrm{C}$ (Downey et al., 2006).

Proanthocyanidin accumulation reaches a peak close to veraison and decreases towards harvest. This could be ascribed to its extractability rather than a degradation or turnover (Cheynier et al., 1997; De Freitas \& Glories, 1999; Kennedy et al., 2001; Ó-Marques et al., 2005). The amount of seed tannin in berries is related to the number of seeds per berry (Habertson \& Adams, 2002). Cohen et al. (2008) studied the effect of temperature during the green berry stage and maturation. Proanthocyanidin accumulation was linearly related to the heat summation during the grape development period. Yet, damping of the diurnal temperature by daytime cooling and night-time heating resulted in a reduction in the proanthocyanidin mDP. Downey et al. (2004) suggested that shading had no significant effect on the levels of condensed tannins in the skins or seeds of ripe fruit. However, there were noticeable differences in the total condensed tannins over two vintages. These differences were ascribed to changes in the skin tannin content. Cohen et al. (2012) found that heating and cooling of berries from $20.5^{\circ} \mathrm{C}$ by $\pm 8^{\circ} \mathrm{C}$ altered the initial rates of proanthocyanidin accumulation. However, the total proanthocyanidin accumulation was not related to the thermal time, but is more likely a function of berry development within a particular season.

\section{Water constraint/stress}

Irrigation of vineyards is a worldwide practice in arid and semi-arid regions, and it has been found that it affects the biosynthesis of phenolics (Cohen \& Kennedy, 2010). Roby et al. (2004a; 2004b) found an increase in the skin tannins and anthocyanin amounts per berry, as well as concentrations with an increased water deficit. Ojeda et al. (2001; 2002) studied the impact of water deficits during different berry growth stages. Smaller berries and higher skin flavonol concentrations were correlated with water stress during berry green growth stages. Proanthocyanidin and anthocyanin concentrations were also impacted as the skin-to-pulp weight ratio increased due the induced water stress applied before and/or after veraison. The latter findings correlate with other studies (Kennedy et al., 2002b; Petrie et al., 2004; Salon et al., 2005; Koundouras et al. 2006). Castellarin et al. (2007) found that water deficit before and after veraison resulted in a reduction in berry size, and the flavonol concentrations were affected by the timing of the irrigation. An increase in proanthocyanidin concentration 
was noted after veraison, but was similar for all treatments (early and late deficit irrigation) at harvest. In general, the timing of water constraint/water stress (i.e. before or after veraison), the water constraint levels and the duration of the water constraints will affect the concentration of major phenols (Deloire et al., 2004).

\section{Ultra-violet radiation}

Fruit composition is affected by photosynthetic, UV, thermal and phytochrome effects (Smart, 1987; Kolb et al., 2001; Kolb et al., 2003; Berli et al., 2010). Light movement occurs through a passage of different tissue layers via light scattering. Therefore, plants can be described as a complex optical system (Smith, 1975). After light passes through the plant surface, the spectral quality and quantity may be altered by wavelength dependent absorption (Smith, 1975).

Plant photosynthesis is sustained by the "visible" range of the spectrum on the earth surface (400-800 nm). However, when the visible spectrum radiation is gathered, plants are also exposed to UV radiation in the wavelength range 290 $400 \mathrm{~nm}$. UV radiation can be divided into UV-A (315-400 $\mathrm{nm})$, UV-B (280-320 nm) and UV-C (<280 nm) ranges. Morphogenetic changes in plants have been caused by UV-B radiation (Rozema et al., 1997). Furthermore, Jordan (1996), Rozema et al. (1997), Vass (1997), and Hollósy (2002) found damage to lipids, nucleic acids, and proteins. Teramura \& Sullivan (1994) reviewed the primary, secondary, and indirect effects of UV-B radiation on photosynthesis. Plant morphogenetic parameters that are changed are plant height, leaf area, leaf thickness, branching, and plant phenology (Tevini \& Steinmuller, 1987; Barnes et al., 1990; Ryel et al., 1990; Bornman \& Vogelmann, 1991; Teramura \& Sullivan, 1994). UV-B radiation affects the secondary metabolism of plants. Secondary metabolite production can be stimulated by UV-B as well as the prevailing abiotic and biotic conditions (Rozema et al., 1997).

UV-B radiation affects some enzymes of the phenylpropanoid pathway. PAL and CHS activity are stimulated by UV-B radiation (Jansen et al., 1998; Pontin et al., 2010). PAL catalyses the deamination of phenylalanine to form trans-cinnamic acid. Hydroxycinnamic acids are particularly effective in screening out UV-B radiation as they absorb effectively in the $300 \mathrm{~nm}$ range of the UV-B spectral region, whereas flavonoids absorb at $280 \mathrm{~nm}$. Flavonoids absorb UV-B radiation; and epidermal flavonoids, in particular, act as UV-B screens for interior tissues of leaves and stems. Elevated levels of UV-B radiation are known to cause a limited increase of tannins and lignin (Gehrke et al., 1996).

The impact of UV radiation on grapevine functioning was at the centre of various studies. Kolb et al. (2001) found increased levels of hydroxycinnamic acids (coumaric and caffeic acid) in sun-exposed grape leaves. In the berries, however, lower levels of hydroxycinnamic acids were obtained with increased radiation, while similar to grapevine leaves, quercetin and kaempferol increased (Kolb et al., 2003). Spayd et al. (2002) studied the effect of UV barriers over the canopy and fruiting zone over a 2 -year period. Flavonol biosynthesis was influenced by UV barriers, as individual and total flavonol concentration was significantly reduced when UV absorbing material barriers were used. Koyama et al. (2012) suggested that UV exclusion did not affect the concentration and composition of proanthocyanidins, but confirmed a decrease in flavonol concentration. Gregan et al. (2012) suggested that the composition of flavonols in the skins of Sauvignon blanc grapes is determined by UV-B radiation.

\section{Sensory properties of grape and wine phenolics}

Phenolic compounds in wine contribute to the wine sensorial properties (wine colour, astringency, bitterness and mouthfeel) and antioxidative properties (Gawel, 1998). Phenolic levels in wine can be affected by several factors such as grape genotypes (Ricardo-da-Silva et al., 1992b; Sun et al., 2001), the winemaking practices and the conditions of wine ageing and storage (Sun et al., 1999; Sun et al., 2001). The conversion of anthocyanins and proanthocyanidins to other polymeric species contributes to the change in colour and taste of a wine. The impact of polymerisation reactions on wine sensory properties is largely unknown. Some researchers suggest a contribution of newly formed polymeric pigments to astringency mouthfeel (Oberholster, 2009), and others suggest a decrease of wine astringency (Weber et al., 2013; Wollmann \& Hofmann, 2013).

Monomeric and polymeric flavan-3-ols are the primary contributors to the astringency and bitterness character of red wine (Singleton \& Trousdale, 1992). Astringency is a tactile sensation in which drying, puckering, and roughing are produced by the interactions of wine tannins with salivary proteins (Robichaud \& Noble, 1990). Bitterness is a taste sensation perceived by each of the several thousand sensors on the tongue (Katsnelson, 2015). Astringency perception is not well understood, but can be caused by (i) an increase in friction, (ii) interaction between tannins and oral epithelial proteins/taste receptors, and (iii) change in salivary viscosity (Gawel, 1998; McRae \& Kennedy, 2011). Protein-polyphenol interactions can be divided into (i) hydrophobic interactions, and (ii) hydrogen bonding, which is influenced by the degree of polymerisation, galloylation, and hydroxylation of tannins (Gawel, 1998; Peleg et al., 1999). (+)-Catechin exhibits bitterness and astringency in white wine solutions (Arnold et al., 1980; Robichaud \& Noble, 1990). Five concentrations ranging between 0-1200 $\mathrm{mg} / \mathrm{L}$ was evaluated by Robichaud \& Noble (1990), while three concentrations between $160-300 \mathrm{mg} / \mathrm{L}$ was studied by Arnold et al. (1980) in base wine. Thorngate and Noble (1995) showed that the intensity of astringency and bitterness of two monomeric flavan-3-ols - (-)-epicatechin and (+)-catechindiffers with (-)-epicatechin, having a higher intensity than $(+)$-catechin. Three concentration levels $(0.5,0.9$ and $1.2 \mathrm{~g} / \mathrm{L}$ of (-)-epicatechin and (+)-catechin) in a model wine solution were assessed.

Chira et al. (2008) found a positive correlation between astringency intensity and mean degree of polymerisation (mDP) in grape skins (mDP 23.1 and 20.94 in 2006 and 2007 vintages, respectively). Both astringent and bitterness perception thresholds are influenced by the concentrations. Therefore, a higher concentration results in an increase in the intensity of the sensation. Astringency and bitterness are influenced by the mDP of polymers. With an increased chain 
length, both bitterness and astringency increase. However, astringency increases faster than bitterness (Arnold et al., 1980; Lea \& Arnold, 1978; Gawel 1998). Peleg et al. (1999) found that bitterness is elicited by an interaction with a specific bitter membrane-bound receptor or through surface membrane interactions. Therefore, an increase in molecular size of procyanidins decreases bitterness by limiting the access to a membrane-bound receptor or by direct depolarisation of the taste receptor cell. Lea \& Arnold (1978) suggested that the increase in the perceived astringency with the $\mathrm{mDP}$ is due to greater capacity of polyphenols to bind the proteins and stimulate astringency. Vidal et al. (2003) suggested that the mDP in apple and grape extracts were the most discriminatory structural variable as astringency increased with an increase in polymerisation. An increase in the galloylation can result in an increase in coarseness, while trihydroxylation of the B-ring decreased coarseness (Vidal et al., 2004a). Vidal et al. (2004b) suggested that anthocyanins in their glucoside and coumaroylated forms did not influence astringency and bitterness of model wine solutions. However, polysaccharides play an important role in the mouthfeel properties of wine. Acidic polysaccharides significantly decreased the astringency, while neutral polysaccharides had less of an effect in a model wine solution. Other parameters that affect the intensity and duration of astringent and bitter sensations by altering the salivary flow and composition are (i) wine $\mathrm{pH}$, (ii) ion concentration, (iii) temperature, and (iv) ethanol concentration (Gawel, 1998).

\section{CONCLUSIONS}

The composition of wine grape berries is affected by genotype, clones, abiotic factors and cultural practices. Therefore, grape quality is a complex concept that depends on berry composition and size. Grape berry composition is affected by abiotic factors (light, temperature, soil water content, wind, as well as air humidity) mainly at the mesoand microclimatic levels.

Plants are complex optical systems that are dependent on the light environment (visible light and UV) amongst other parameters. The light environment is affected by both longterm (row direction, vine spacing, trellising system, etc.) and short-term practices (canopy manipulations, pruning, and trellising that will affect the architecture of the canopy).

Berry temperature is important, as it is affected not only by sunlight exposure, but also by the availability of water to maintain transpiration. Increased exposure to sunlight from an early stage of berry development, as well as the availability of water, has an effect on the fruit growth and composition. Sunlight exposure $\left(>100 \mu \mathrm{mol} \mathrm{m}^{-2} / \mathrm{s}^{-1}\right)$, combined with simultaneous high temperatures, lead to a decrease in phenolic compounds such as anthocyanins and total phenolics. Grapevine water deficit is used as a tool to manage the synthesis of secondary metabolites.

It can be said that vine metabolism (and overall performance) is affected by a complex interaction between natural and man-made factors. At the microclimatic level, the management of light quantity and quality is a powerful tool to regulate the quantitative and qualitative performance of the vine. This review contributes to the knowledge around the effect of sunlight and temperature on grapevine berry responses to bunch and canopy microclimatic changes. By determining, under controlled conditions, the possible effect of these two abiotic factors at the bunch microclimatic level, it should be possible to establish thresholds of light and temperature effect on berry growth and phenolic biosynthesis.

Working in a vineyard, the impact of terroir concept will not be fully comprehended because of the number of variables linked to this notion (soil, meso-climatic, and vines differences). The prevailing conditions within a terroir unit will, therefore, impact the abiotic factors and the threshold values as it has been demonstrated within the literature study. This complicates our understanding of the effects of light, temperature, and vine water status on berry phenolics composition.

\section{LITERATURE CITED}

Adams, D., 2006. Phenolics and ripening in grape berries. Am. J. Enol. Vitic. 57, 249-256.

Ali, K., Maltese, F, Choi, Y.H. \& Verpoorte, R., 2010. Metabolic constituents of grapevine and grape-derived products. Phytochem. Rev. 9, 357-378.

Arnold, R.A., Noble, A.C. \& Singleton, V.L., 1980. Bitterness and astringency of phenolic fractions in wine. J. Agric. Food Chem. 28, 686680

Barnes, P.W., Flint, S.D. \& Caldwell, M.M., 1990. Morphological responses of crop and weed species of different growth forms to ultraviolet-B radiation. Am. J. Bot. 77, 1354-1360.

Bergqvist, J., Dokoozlian, N. \& Ebisuda, N., 2001. Sunlight exposure and temperature effects on berry growth and composition of Cabernet Sauvignon and Grenache in the central San Joaquin Valley of California. Am. J. Enol. Vitic. 5, 1-7.

Berli, F.J., Moreno, D., Piccoli, P., Hespanhol-Viana, L., Silva, M.F., Bressan-Smith, R., Cavagnaro, J.B. \& Bottini, R., 2010. Abscisic acid is involved in the response of grape (Vitis vinifera $\mathrm{L}$.) $\mathrm{cv}$. Malbec leaf tissues to ultraviolet-B radiation by enhancing ultraviolet-absorbing compounds, antioxidant enzymes and membrane sterols. Plant Cell Environ. 33, 1-10.

Bogs, J., Downey, M.O, Harvey, J.S., Ashton, A.R., Tanner, G.J. \& Robinson, S.P., 2005. Proanthocyanidin synthesis and expression of genes encoding leucoanthocyanidin reductase and anthocyanidin reductase in developing grape berries and grapevine leaves. Plant Physiol. 139, 652-663.

Bogs, J., Ebadi, A., McDavid, D. \& Robinson, S.P., 2006. Identification of the flavonoid hydroxylases from grapevine and their regulation during fruit development. Plant Physiol. 140, 279-291.

Bornman, J.F. \& Vogelmann, T.C., 1991. Effect of UV-B radiation on leaf optical properties measured with fibre optics. J. Exp. Bot. 42, 547-554.

Bucchetti, B., Matthews M.A., Falginella, L., Peterlunger, E. \& Castellarin, S.D., 2011. Effect of water deficit on Merlot grape tannins and anthocyanins across four seasons. Sci. Hortic. 128, 297-305.

Buttrose, M.S., Hale, C.R. \& Kliewer, W.M., 1971. Effect of temperature on the composition of 'Cabernet Sauvignon' berries. Am. J. Enol. Vitic. 22, $71-75$.

Castellarin, S.D., Di Gaspero, G., Marconi, R., Nonis, A., Peterlunger, E., Paillard, S., Adam-Blondon, A.F. \& Testolin, R., 2006. Colour variation in red grapevines (Vitis vinifera L.): Genomic organization, expression of flavonoid 3'-hydroxylase, flavonoid 3', 5'-hydroxylase genes and related metabolite profiling of red cyanidin-/blue delphinidin-based anthocyanins in berry skin. BMC Genomics. 12, 1-17. 
Castellarin, S.D, Mathews, M.A., Di Gaspero, G. \& Gambetta, G.A., 2007. Water deficits accelerate ripening and induce changes in gene expression regulating flavonoid biosynthesis in grape berries. Planta. 227, 101-112.

Castellarin, S.D., Bavaresco, L., Falginella, L., Gonçalves, M.I.V.Z., Di Gaspero, G., 2012. Phenolics in Grape Berry and Key Antioxidants. In The Biochemistry of the grape berry; Gerós, H., Chaves, M., Delrot, S., Eds.; Bentham Science, Bussum.

Chalmers, D.J. \& Faragher, J.D., 1977. Regulation of anthocyanin synthesis in apple skin. III: Involvement of phenylalanine ammonia-lyase. Austral. J. Plant Physiol. 4, 133-141.

Cheynier, V. \& Rigaud, J., 1986. HPLC separation and characterisation of flavonols in the skin of Vitis vinifera var. Cinsault. Am. J. Enol. Vitic. 37, $248-252$.

Cheynier, V., Fulcrand, H., Sarni, P. \& Moutounet, M., 1997. Reactivity of phenolic compounds in wine: diversity of mechanisms and resulting products. In: Vino Analytica Scientia. Bordeaux.

Cheynier, V., Fulcrand, H., Brossaud, F., Asselin, C. \& Mountounet, M. 1998. Phenolic composition as related to red wine flavour. In: Waterhouse, A. \& Ebeler, S. (eds). Wine flavour. ACS Symposium Series. 174, 124-141.

Cheynier, V., Dueñas-Paton, M., Salas, E., Maury, C, Jean-Marc Souquet, J., Sarni-Manchado, P. \& Fulcrand, H., 2006. Structure and properties of wine pigments and tannins. Am. J. Enol. Vitic. 57, 298-305.

Chira, K., Schmauch, G., Saucier, C., Fabre, S. \& Teissedre, P., 2008. Grape variety effect on proanthocyanidin composition and sensory perception of skin and seed tannin extracts from Bordeaux wine grapes (Cabernet Sauvignon and Merlot) for two consecutive vintages (2006 and 2007). J. Agric. Food Chem. 57, 545-553.

Chorti, E., Guidoni, S., Ferrandino, A. \& Novello, V., 2010. Effect of different cluster sunlight exposure levels on ripening and anthocyanin accumulation in Nebbiolo grapes. Am. J. Enol. Vitic. 61, 23-29.

Cohen, S.D., Tarara, J.M. \& Kennedy, J.A., 2008. Assessing the impact of temperature on grape phenolic metabolism. Anal. Chim. Acta. 621, 57-67.

Cohen, S.D. \& Kennedy, J.A., 2010. Plant metabolism and the environment: Implications for managing phenolics. Crit. Rev. Food Sci. Nutr. 50, 620 643.

Cohen, S.D., Tarara, J.M., Gambetta, G.A., Matthews, M.A. \& Kennedy, J.A., 2012. Impact of diurnal temperature variation on grape berry development, proanthocyanidin accumulation, and the expression of flavonoid pathway genes. J. Exp. Bot. 1-11.

Conde, C., Silva, P., Fontes, N., Dias, A.C.P., Tavares, R.M., Sousa, M.J., Agasse, A., Delrot, S. \& Gerós, H., 2007. Biochemical changes throughout grape berry development and fruit and wine quality. In: Global Science Books, Food. 1,1-22

Coombe, B.G., 1987. Distribution of solutes within the developing grape berry in relation to its morphology. Am. J. Enol. Vitic. 38, 120-127.

Cortell, J.M., Halbleib, M., Gallagher, A.V., Righetti, T.L. \& Kennedy, J.A. 2005. Influence of vine vigor on grape (Vitis vinifera L. cv Pinot noir) and wine proanthocyanidins. J. Agric. Food Chem. 53, 5798-5808.

Crippen, D.D.J. \& Morrison, J.C., 1986. The effects of sun exposure on the phenolic content of Cabernet Sauvignon berries during development. Am. J. Enol. Vitic. 37, 243-247.

Czochanska, Z., Foo, L.Y. \& Porter, L.J. 1979. Compositional changes in lower molecular weight flavans during grape maturation. Phytochemistry. $18,1819-1822$.

Davies, K.M. \& Schwinn, K.E., 2006. Molecular biology and biotechnology of flavonoid biosynthesis. In: Flavonoids: Chemistry, biochemistry and applications. CRC Press, Boca Raton FL.
De Freitas, V.A.P. \& Glories, Y., 1999. Concentration and compositional changes of procyanidins in grape seeds and skins of white Vitis vinifera varieties. J. Sci. Food Agric. 79, 1601-1606.

Deloire, A., Carbonneau, A., Wang, Z. \& Ojeda, H., 2004. Vine and water, a short review. J. Int. Sci. Vigne Vin. 38, 1-13.

Dewick, M. \& Haslam, E., 1969. The biosynthesis of gallic acid in higher plants. Biochem. J. 113, 537-542.

Dokoozlian, N.K. \& Kliewer, W.M., 1996. Influence of light on grape berry growth and composition varies during fruit development. J. Am. Soc. Hort. Sci. $121,869-874$

Dong, Y.H., Beuning L., Davies, K., Mitra, D., Morris, B. \& Kootstra, A., 1998. Expression of pigmentation genes and photo-regulation of anthocyanin biosynthesis in developing Royal Gala apple flowers. Aust. J. Plant Physiol. 25, 245-252.

Downey, M.O., Harvey, J.S. \& Robinson, S.P., 2003a. Analysis of tannins in seeds and skins of Shiraz grapes throughout berry development. Aust. J. Grape Wine Res. 9, 15-27.

Downey, M.O., Harvey, J.S. \& Robinson, S.P., 2003b. Synthesis of flavonols and expression of flavonol synthase genes in the developing grape berries of Shiraz and Chardonnay (Vitis vinifera L.). Aust. J. Grape Wine Res. 9 , 1101-1121

Downey, M.O., Harvey, J.S. \& Robinson, S.P., 2004. The effect of bunch shading on berry development and flavonoid accumulation in Shiraz grapes. Aust. J. Grape Wine Res. 10, 55-73.

Downey, M.O., Dokoozlian, N.K. \& Krstic, M.P., 2006. Cultural practice and environmental impacts on the flavonoid composition of grapes and wine: A review of recent research. Am. J. Enol. Vitic. 57, 257-268.

Ebadi, A., May, P., Sedgley, M. \& Coombe, B.G., 1995. Fruit set on small Chardonnay and Shiraz vines grown under varying temperature regimes between budburst and flowering. Aust. J. Grape Wine Res. 1, 1-10.

Gawel, R., 1998. Red wine astringency: A review. Aust. J. Grape Wine Res. 4, 74-95.

Gehrke, C., Johansson, U., Gwynn-Jones, D., Björn, L.O., Callaghan, T.V. \& Lee, J.A., 1996. Effects of enhanced ultraviolet-B on terrestrial subartic ecosystems and implications for interactions with increased $\mathrm{CO}_{2}$. Ecol. Bull. 45, 192-203.

Gladstones, J., 1992. Viticulture and Environment. Winetitles, Adelaide.

Gregan, S.M., Wargent, J.J., Liu, L., Shinkle, J., Hofmann, Winefield, C., Trought, M. \& Jordan, B., 2012. Effects of solar ultraviolet radiation and canopy manipulation on the biochemical composition of Sauvignon Blanc grapes. Aust. J. Grape Wine Res. 18, 227-238.

Habertson, F. \& Adams, J. A., 2002. Tannins in skins and seeds of Cabernet Sauvignon, Syrah and Pinot noir berries during ripening. Am. J. Enol. Vitic. $53,54-59$.

Haselgrove, L., Botting, D., van Heeswijck, R., Høj, P.B., Dry, P.R., Ford, C. \& Iland, P.G., 2000. Canopy microclimate and berry composition: The effect of bunch exposure on the phenolic composition of Vitis vinifera L cv. Shiraz grape berries. Aust. J. Grape Wine Res. 6, 141-149.

Haslam, E., 1998. Practical polyphenolics: from structure to molecular recognition and physiological action. University Press, Cambridge.

Hawker, J.S., 1982. Effect of temperature on lipid, starch and enzymes of starch metabolism in grape, tomato and broad bean leaves. Phytochem. 21, 33-36.

Heller, W. \& Forkmann, G., 1988. Biosynthesis. In: The Flavonoids: Advances in Research since 1980. Harborne J.B. (ed.). Chapman and Hall, London. 
Hollósy, F., 2002. Effects of ultraviolet radiation on plant cells. Micron. 33, 179-197.

Hunter, J.J., De Villiers, O.T. \& Watts, J.E., 1991. The effect of partial defoliation on quality characteristics of Vitis vinifera L. cv. Cabernet Sauvignon grapes. II. Skin color, skin sugar, and wine quality. Am. J. Enol. Vitic. 42, 13-18.

Jackson, D.I. \& Lombard, P.B., 1993. Environment and management practices affecting grape composition and wine quality - A review. Am. J. Enol. Vitic. 44, 409-430.

Jansen, M.A.K., Gaba, V. \& Greenberg, B.M., 1998. Higher plants and UV-B radiation: balancing damage, repair and acclimation. Trends Plant Sci. 3, 131-135

Jordan, B.R., 1996. The effects of ultraviolet-B radiation on plants: a molecular perspective. In: Advances in Botanical Research 2 vol. 22.J.A. Callow (ed.). Academic Press Ltd,

Jordão, A.M., Ricardo-da-Silva, J.M. \& Laureano, O., 2001. Evolution of catechins and oligomeric procyanidins during grape maturation of Castelão Francês and Touriga Francesa. Am. J. Enol. Vitic. 52, 230-234.

Jones, G., Davis, R., 2000. Climate influences on grapevine phenology, grape composition, and wine production and quality for Bordeaux, France. Am. J. Enol. Vitic. 51, 249-261.

Katsnelson, A., 2015. From the tongue to the brain. A body of research by Charles Zuker explains how we distinguish bitter from sweet, salty from sour - and why we should care. Available: http://www. columbiamedicinemagazine.org/features/spring-2015/tongue-brain. (Accessed: 1 June 2015)

Kennedy, J.A., Matthews, M.M. \& Waterhouse, A.L., 2000a. Changes in grape seed polyphenols during fruit ripening. Phytochem. 55, 77-85.

Kennedy, J.A., Troup, G.J., Pilbrow, J.R., Hutton, D.R., Hewitt, D., Hunter, C.R., Ristic, R., Iland, P.G. \& Jones, G.P., 2000b. Development of seed polyphenols in berries from Vitis vinifera L. cv. Shiraz. Aust. J. Grape Wine Res. 6, 244-254

Kennedy, J.A., Hayasaka, Y., Vidal, S., Waters, E.J. \& Jones, G.P. 2001. Composition of grape skin proanthocyanidins at different stages of berry development. J. Agric. Food Chem. 49, 5348-5355.

Kennedy, J.A., 2002a. Understanding grape berry development. Practical Winery. Available: http://www.practicalwinery.com?JulyAugust02/ julaug02p14.htm. (Accessed: 21/11/2012).

Kennedy, J.A., Matthews, M.A. \& Waterhouse, A.L., 2002b. Effect of maturity and vine water status on grape skin and wine flavonoids. Am. J. Enol. Vitic. 53, 268-274.

Kliewer, W.M. \& Antcliff, A.J., 1970. Influence of defoliation, lea darkening, and cluster shading on the growth and composition of 'Sultana' grapes. Am. J. Enol. Vitic. 21, 26-36.

Kliewer, W.M. \& Torres, R.E., 1972. Effect of controlled day and night temperatures on grape coloration. Am. J. Enol. Vitic. 23, 71-77.

Kliewer, W.M., 1977. Influence of temperature, solar radiation and nitrogen on coloration and composition of Emporer grapes. Am. J. Enol. Vitic. 28, 96-103.

Kolb, C.A., Käser, M.A., Kopecký, J., Zotz, G., Riederer, M. \& Pfündel, E.E., 2001. Effects of natural intensities of visible and ultraviolet radiation on epidermal ultraviolet screening and photosynthesis in grape leaves. Plant Physiol. 127, 863-875.

Kolb, C.A., Kopecký, J., Riederer, M. \& Pfündel, E.E., 2003. UV screening by phenolics in berries of grapevine (Vitis vinifera). Funct. Plant Biol. 30, 1177-1186.
Koundouras, S., Marinos, V., Gkoulioti, A., Kotseridis, Y. \& Van Leeuwen, C., 2006. Influence of vineyard location and vine water status on fruit maturation of non-irrigated cv. Agiorgitiko (Vitis vinifera L.). Effects on wine phenolic and aroma components. J. Agric. Food Chem. 54, 5077-5086.

Koundouras, S., Hatzidimitriou, E., Karamolegkou, M., Dimopoulou, E., Kallithraka, S., Tsialtas, J.T., Zioziou, E., Nikolaou, N., \& Kotseridis, Y., 2009. Irrigation and Rootstock Effects on the Phenolic Concentration and Aroma Potential of Vitis vinifera L. cv. Cabernet Sauvignon Grapes. J. Agric. Food Chem. 57, 7805-7813.

Koyama, K., Ikeda, H., Poudel, P.R. \& Goto-Yamamoto, N., 2012. Light quality affects flavonoid biosynthesis in young berries of Cabernet Sauvignon grape. Phytochemistry. 78, 54-64

Labarbe, B., Cheynier, V., Borssaud, F., Souquet, J.M. \& Moutounet, M., 1999. Quantitative fractionation of grape proanthocyanidins according to their degree of polymerisation. J. Agric. Food Chem. 2719-2723.

Laget, F., Tondut, J., Deloire, A., Kelly, M., 2008. Climate trends in a specific Mediterranean viticultural area between 1950 and 2006 (in France) J. Int. Sci. Vigne. 42, 113-123.

Lancaster, J.E., 1992. Regulation of skin color in apples. CRC Crit. Rev. Plant Sci. 10, 487-502.

Lea, A.G.H. \& Arnold, G.M., 1978. The phenolics of ciders: bitterness and astringency. J. Sci. Food Agric. 29, 478-483.

Lee, C.Y. \& Jaworski, A.W., 1987. Phenolic compounds in white grapes grown in New York. Am. J. Enol. Vitic. 38, 2772-2781.

Mané, C., Souquet, J.M., Ollé, D., Verriès, C., Véran, F., Mazerolles, G., Cheynier, V. \& Fulcrand, H., 2007. Optimization of simultaneous flavanol, phenolic acid and anthocyanin extraction from grapes using an experimental design: application to the characterization of Champagne grape varieties. J. Agric. Food Chem. 55, 7224-7233.

Martínez-Lüscher, J., Chen, C.C.L., Brillante, L. \& Kurtural, S.H., 2017. Partial solar radiation exclusion with color shade nets reduces the degradation of organic acids and flavonoids of grape berry (Vitis vinifera L.). J. Agric. Food Chem. 65, 10693-10702.

Mattivi, F., Guzzon, R., Vrhovsek, U., Steffanini, M. \& Velasco, R., 2006. Metabolite profiling of grape: flavonols and anthocyanins. J. Agric. Food Chem. 54, 7692-7702.

McRae, J. \& Kennedy, J.A., 2011. Wine and grape tannin interactions with salivary proteins and their impact on astringency: A review of current research. Molecules. 16, 2348-2364.

Mori, K., Sugaya, S. \& Gemma, H., 2005. Decreased anthocyanin biosynthesis in grape berries grown under elevated night temperature conditions. Sci. Hortic. 105, 319-330.

Mori, K., Goto-Yamamoto, N., Kitayama, M. \& Hashizume, K., 2007. Loss of anthocyanins in red wine grape under high temperature. J. Exp. Bot. 58, 1935-1945.

Morrison, J. C. \& Noble, A.C., 1990. The effects of leaf and cluster shading on the composition of Cabernet Sauvignon grapes and on fruit and wine sensory properties. Am. J. Enol. Vitic. 41, 193-200.

Moutounet, M., Rigaud, J., Souquet, J. \& Cheynier, V., 1996. Caractérisation structurale des tanins de la baie de raisin. Quelques exemples de l'incidence du cépage, du terroir et du mode de conduite de la vigne. Bulletin OIV. 433-443.

Oberholster, A., Francis, I.L., Iland, P.G. \& Waters, E.J., 2009. Mouthfeel of white wines made with and without pomace contact and added anthocyanins. Aust. J. Grape Wine Res. 15, 59-69.

Ojeda, H., Deloire, A. \& Carbonneau, A., 2001. Influence of water deficits on grape berry growth. Vitis. 40, 141-145 
Ojeda, H., Andary, C., Kraeva, E., Carbonneau, A. \& Deloire, A., 2002. Influence of pre- and postvéraison water deficit on synthesis and concentration of skin phenolic compounds during berry growth of Vitis vinifera cv. Syrah. Am. J. Enol. Vitic. 53, 261-267.

OIV (Organisation Internationale de la Vigne et du Vin), 2013. Global Economic Survey. Available: http://www.google.co.za/url?url=http:// www.oiv.int/oiv/files/EN_point\%2520de\%2520conj.pdf (Accessed: 02 December 2014).

Ó-Marques, J., Reguinga, R., Laureano, O. \& Ricardo-da-Silva, J.M., 2005. Alterações ao longo da maturação nos taninos condensados da grainha, película e polpa: influência da monda de cachos. Cienc. Tec. Vitivinic. 20, 35-52.

Orduña, R., 2010. Climate change associated effects on grape and wine quality and production. Food Res. Int. 43, 1844-1855.

Petrie, P.R., Cooley N.M. \& Clingeleffer, P.R., 2004. The effect of postveraison water deficit on yield components and maturation of irrigated Shiraz (Vitis vinifera L.) in the current and following season. Aust. J. Grape Wine Res. 10, 203-215.

Petrie, P.R. \& Sadras, V.O., 2008. Advancement of grapevine maturity in Australia between 1993 and 2006: Putative causes, magnitude of trends and viticultural consequences. Aust. J. Grape Wine Res. 14, 33-45.

Peleg, H., Gacon, K., Schlich, P. \& Noble, A.C., 1999. Bitterness and astringency of flavan-3-ol monomers, dimers and trimers. J. Sci. Food Agric. 79, 1123-1128.

Piretti, M.V., Ghedini, M. \& Serrazanetti, G., 1976. Isolation and identification of the polyphenolic and terpenoid constituents of Vitis vinifera. v. Trebbiano variety. Ann Chim, Rome. 66, 429-437.

Price, S.F., Breen, P.J, Valladao, M. \& Watson, B.T., 1995. Cluster sun exposure and quercetin in Pinot noir grapes and wine. Am. J. Enol. Vitic. 46, 187-194.

Prieur, C., Rigaud, J., Cheynier, V. \& Moutounet, M., 1994. Oligomeric and polymeric procyanidins form grape seeds. Phytochemistry. 36, 781-784.

Pontin, M.A., Piccoli, P.N., Francisco, R., Bottini, R, Martinez- Zapater, J.M., Lijavetzky, D., 2010. Transcriptome changes in grapevine (Vitis vinifera L.) cv. Malbec leaves induced by ultraviolet-B radiation. BMC Plant Biol. 2010, 10.

Reshef, N., Agam, N. \& Fait, A., 2018. Grape berry acclimation to excessive solar irradiance leads to repartitioning between major flavonoid groups. J. Agric. Food Chem. 66, 3624-3636.

Ribereau-Gayon, P., Dubourdieu, D., Doneche, B. \& Lonvaud, A., 2000 $\left(2^{\text {nd }}\right.$ ed). Handbook of Enology. Volume 1. John Wiley and Sons Ltd, West Sussex.

Ricardo-da-Silva, J.M., Rigaud, J., Cheynier, V., Cheminat, A. \& Moutounet, M. 1991a. Procyanidin dimers and trimers from grape seeds. Phytochem. 30, 1259-1264.

Ricardo-da-Silva, J.M., Bourzeix, M., Cheynier, V. \& Moutounet, M., 1991b. Procyanidin composition of Chardonnay, Mauzac and Grenanche blanc grapes. Vitis. 30, 245-252.

Ricardo-da-Silva, J.M., Cheynier, V., Souquet, J.M. \& Moutounet, M., 1991c. Interaction of grape seed procyanidins with various proteins in relation to wine fining. J. Sci. Food Agric. 57, 111-125.

Ricardo-da-Silva, J.M., Rosec, J.P., Mourgues, J. \& Moutounet, M., 1992a. Dimer and trimer procyanidins in Carignan and Mourvedre grapes and wines. Vitis. 31, 55-63.

Ricardo-da-Silva, J.M., Belchior, A.P. \& Spranger, M.I., 1992b. Oligomeric procyanidins of three grapevine varieties and wines from Portugal. Sci Aliment. 12, 223-237.
Ristic, R., Downey, M.O., Iland, P.G., Bindon, K., Francis, I.L., Herderich, M. \& Robinson, S.P., 2007. Exclusion of sunlight from Shiraz grapes alters wine colour, tannin and sensory properties. Austr. J. Grape Wine Res. 13, 53-65.

Robichaud, J.L. \& Noble, A.C., 1990. Astringency and bitterness of selected phenolics in wine. J. Sci. Food Agric. 53, 343-353.

Roby, G., Harbertson, J.F., Adams, D.O. \& Matthews, M.A., 2004a. Berry size and vine water deficits as factors in wine grape composition: Anthocyanins and tannins. Aust. J. Grape Wine Res. 10, 100-107.

Roby, G. \& Matthews, M.A., 2004b. Relative proportions of seed, skin and flesh in ripe berries from Cabernet Sauvignon grapevines grown in a vineyard either well irrigated or under water deficit. Aust. J. Grape Wine Res. 10, 74-82.

Rozema, J., van de Staaij, J., Bjorn, L.O. \& Caldwell, M., 1997. UV-B as an environmental factor in plant life: stress and regulation. Trends Ecol. Evol. 12, 22-28.

Ryel, R.J., Barnes, P.W., Beyschlag, W., Caldwell, M.M. \& Flint, S.D., 1990. Plant competition for light analyzed with a multispecies canopy model. I. Model development and influence of enhanced UV-B conditions on photosynthesis in mixed wheat and wild oat canopies. Oecologia. 82, 304-310.

Salon, J.L., Chirivella, C. \& Castel, C.R., 2005. Response of cv. Bobal to timing of deficit irrigation in Requena, Spain: Water relations, yield, and wine quality. Am. J. Enol. Vitic. 56, 1-8.

Schwinn, K.E. \& Davies, K.M., 2004. Flavonoids. In: Davies, K.M. (ed). Plant Pigments and their Manipulation. Blackwell Publishing Ltd, Oxford.

Siegelman, H.W. \& Hendricks, S.B., 1958. Photocontrol of anthocyanin synthesis in apple skin. Plant Physiol. 33, 185-190.

Singleton, V.L. \& Trousdale, E.K., 1992. Anthocyanin-tannin interactions explaining differences in polymeric phenols between white and red wines. Am. J. Enol. Vitic. 43, 63-70.

Smart, R.E., Robinson, J.B., Due, G.R. \& Brien, C.J., 1985. Canopy microclimate modification for the cultivar Shiraz. 2. Effects on must and wine composition. Vitis. 24, 119-128.

Smart, R.E., 1987. Influence of light on composition and quality of grapes. Acta Hort. 206, 37-47.

Smith, H., 1975. Phytochrome and Photomorphogenesis: An introduction to the photocontrol of plant development. McGraw-Hill, London.

Somers, T.C. \& Vérette, E., 1988. Phenolic composition of natural wine types. In: Linskens, H.F. \& Jackson, J.F. (eds.). Wine analysis. SpringerVerlag, Berlin.

Souquet, J.M., Cheynier, V., Brossaud, F. \& Moutounet, M., 1996. Polymeric proanthocyanidins from grape skins. Phytochemistry. 43, 509-512.

Spayd, S.E., Tarara, J.M., Mee, D.L. \& Ferguson, J.C., 2002. Separation of sunlight and temperature effects on the composition of Vitis vinifera cv. Merlot berries. Am. J. Enol. Vitic. 53, 171-182.

Stafford, H.A., 1990 (1 $1^{\text {st }}$ ed). Flavonoid metabolism. CRC Press, Boca Raton, FL.

Sun, B.S., Pinto, T., Leandro, M.C., Ricardo da Silva, J.M. and Spranger, M.I., 1999. Transfer of catechins and proanthocyanidins from solid parts of the grape cluster into wine. Am. J. Enol. Vitic. 50, 179-184.

Sun, B.S., Spranger, M.I., Roque-do-Vale, F., Leandro, C. \& Belchior, P., 2001. Effect of different winemaking technologies on phenolic composition of Tinta Miura red wines. J. Agric. Food Chem. 49, 5809-5816. 
Tanner, G.J., Francki, K.T., Abrahams, S., Watson, J.M., Larkin, P.J. and Ashton, A.R., 2003. Proanthocyanidin biosynthesis in plants. Purification of legume leucoanthocyanidin reductase and molecular cloning of its own cDNA. J. Biol. Chem. 278, 31647-31656.

Tanner, G., 2006. Condensed tannins. In: Davies, K. (ed). Plant pigments and their manipulation, CRC Press, Blackwell Publishing, UK.

Tarara, J.M., Lee, J., Spayd, S.E. \& Scagel, C., 2008. Berry temperature and solar radiation alter acylation, proportion, and concentration of anthocyanin in Merlot grapes. Am. J. Enol. Vitic. 59, 235-247.

Teramura, A.H. \& Sullivan, J.H., 1994. Effects of UV-B radiation on photosynthesis and growth of terrestrial plants. Photosynt. Res. 39, 463473 .

Terrier, N., Ollé, D., Verriès, C. \& Cheynier, V., 2009. Biochemical \& Molecular Aspects of flavan-3-ol synthesis during berry development. In: Roubelakis-Angelakis, K.A. (ed). Grapevine molecular physiology \& biotechnology. SpringerLink. 2, 365-388.

Tevini, M. \& Steinmuller, D., 1987. Influence of light, UV-B radiation and herbicides on wax biosynthesis of cucumber seedlings. J. Plant Phys. 131, 111-121.

Thorngate, J.H. \& Noble, A.C., 1995. Sensory evaluation of bitterness and astringency of $3 \mathrm{R}(-)$-epicatechin and $3 \mathrm{~S}(+)$-catechin. J. Sci. Food Agric. $67,531-535$.

Vass, I., 1997. Adverse effects of UV-B light on the structure and function of the photosynthetic apparatus. In: Pessarakli, M. (ed). Handbook of photosynthesis. Marcel Dekker, New York.
Vidal, S., Francis, L., Guyot, S., Marnet, N., Kwiatkowski, M., Gawel, R., Cheynier, V. \& Waters, E.J., 2003. The mouth-feel properties of grape and apple proanthocyanidins in a wine-like medium. J. Sci. Food Agric. 83, 564-573.

Vidal, S., Francis, L., Noble, A., Kwiatkowski, M., Cheynier, V. \& Waters, E., 2004a. Taste and mouth-feel properties of different types of tannin-like polyphenolic compounds and anthocyanins in wine. Anal. Chim. Acta. 513, 57-65.

Vidal, S., Francis, L., Williams, P., Kwiatkowski, M., Gawel, R., Cheynier, W. \& Waters, E., 2004b. The mouth-feel properties of polysaccharides and anthocyanins in a wine like medium. Food Chem. 85, 519-525.

Weber, F., Greve, K., Durner, D., Fischer, U. \& Winterhalter, P., 2013. Sensory and chemical characterization of phenolic polymers from red wine obtained by gel permeation chromatography. Am. J. Enol. Vitic. 61, 15-25.

Wicks, A.S. \& Kliewer, W.M., 1983. Further investigations into the relationship between anthocyanins, phenolics and soluble carbo-hydrates in grape berry skins. Am. J. Enol. Vitic. 34, 114-116.

Wollman, N \& Hofmann, T., 2013. Compositional and sensory characterization of red wine polymers. J. Agric. Food Chem. 61, 2045-2061.

Xie, D.Y., Sharma, S.B., Paiva, N.L., Ferreira, D. \& Dixon, R.A., 2003. Role of anthocyanidin reductase, encoded by BANYULS in plant flavonoid biosynthesis. Science. 299, 396-399.

Yamane, T., Jeong, S.T., Goto-Yamamoto, N., Koshita, Y. \& Kobayashi, S., 2006. Effects of temperature on anthocyanin biosynthesis in grape berry skins. Am. J. Enol. Vitic. 57, 54-59.

Zucker, M., 1965. Induction of phenylalanine deaminase by light and its relation to chlorogenic acid synthesis in potato tuber tissue. Plant Physiol. 40, 779-784. 